IDEA - Studia nad strukturą i rozwojem pojęć filozoficznych $\mathrm{XXIX/1}$ Białystok 2017

Katarzyna Popek

(Eódź)

\title{
ON THE DIFFICULT ART OF HUMAN CONDITION. HERMENEUTICS OF NON-KNOWLEDGE
}

\author{
The more you know, \\ the more you know you don't know (Aristotle).
}

The above aphorism in a poetic form presents a weighty for these considerations assertion that the knowledge we have is very sparse, in fact, and the more someone knows, the deeper he or she is convinced that their knowledge means not much. In my article I intend to claim that knowledge perceived as a particularly sanctioned value, is largely a product of rationalization. On the other hand, non-knowledge - from which so far we have cut ourselves off from - is our unavoidable purpose, considering our actual cognitive abilities as well as the necessity of exploring our ignorance. As it was noted by Descartes in Discourse on the Method, the most justly distributed welfare among people is, according to them, good sense. Nobody can deny that they possess common sense. Everyone should play a part in what he or she does best and they ought to go down slowly a straight road rather than run through wilderness. In fact it is the best way to do something in life, achieve some goals and not get lost. ${ }^{1}$ We want to perceive things clearly and distinctly, but as humans we are not perfect. Besides, not everyone is willing to adopt methods of obtaining knowledge proposed by philoso-

${ }^{1}$ R. Descartes, Discourse on the Method, The Radical Academy 2006, http;//www.earlym oderntexts.com/pdf/desdisc.pdf. 
phers. By contrast, the constructivist explanation of phenomena occurring in the surrounding world, resulting in the conclusion that they are epiphenomena generated by a specific system of our brain cells, is not also a fully satisfactory solution to the puzzle that bothers us, because it does not answer the question about who man really is. Scheler, actually tackling this problem, points out that the essence of being human can be proved by the growth to a higher dignity as well as the fall from the heights of the spirit to the present condition ${ }^{2}$. The problem is much more complicated than it seems to be.

\section{The hermeneutic method and its application in the study of non-knowledge}

Taking on the challenge of cognition, studying, searching for the truth, we must begin to internalize it what was previously outside of our inner experience. The re-use of the term "hermeneutic" and the application of this method in the study of "non-knowledge" may actually bring about the awareness of human, previously underestimated, profound misunderstanding about cognition of the world as well as about our personal self-knowledge. On the other hand this "dazzling" is essential; it is something which places us in this world beyond anything we might regard as certain and unchangeable. Only the faintly perceived Transcendence, especially in Karl Jaspers' sense, seems to be something invariably desired, but it is also something passionately deferred in human life. Its ciphers, however, are not pre-set established access passwords, but a specific mosaic of meanings and all of which in their own way simply refer us to their secret.

The explanation of the term "hermeneutics" in the traditional sense turns out to be indispensable, because it opens the unique perspective of reaching the sources of knowledge. Therefore that term "hermeneutics" has a very long and interesting history. The Greek noun "hermeneus" or "hermeneutes" means explainer, the interpreter of the gods. "Hermeneus" thus becomes a mediator between the world of the divine and the human. Due to the fact that the source of such communication is the power exceeding the horizon of the comprehension

${ }^{2}$ M. Scheler, The Idea of Man, trans. C. Nabe, "Journal of the British Society for Phenomenology" No. 9, Oct 1978. 
of mortals engaged in their daily affairs, the meaning of similar messages is never clear. In this sense, hermeneutics is the art of interpretation of the hidden meaning. That meaning transcends beyond the statement and cognitive abilities of the entity, who is its recipient ${ }^{3}$.

It may be that hermeneutics copes with ignorance better than any other method of reaching the truth. Thus, in combination with non-knowledge, hermeneutics gains a wide range of possibilities. Not only does this domain - as an "interpreter" of unknown judgements of Providence - express eternal truths in a way which is closer and closer to their grasp, it also creates space, which can only be occupied by mystery. The lifting-force of the hermeneutic understanding is its nature of self-crossing, climbing beyond oneself, in order to plunge for a moment again into the thicket of confusion and question marks.

Philosophical hermeneutics affirms time and even cultural differences, which traditionally have been considered as hampering the interpretation of the text. The hermeneutic method is a means to get to know oneself, to see one's own reflection in all interpreted texts, especially in that with which the interpreting entity is in dialogue, learning the truth about themselves. According to the hermeneutic tradition, investigation for understanding is a difficult art. It is done by the entangled in differences and contradictions dialogue. Kazimierz Dąbrowski, an innovative Polish psychiatrist and clinical psychologist, author of the well-known, although very controversial, theory of "positive disintegration", pointed out the number of antinomy in reaching the truth about oneself. In order to specify its variations, we can mention about: antinomy of good and evil, love and hate, life and death, specifically Hegelian antinomy of subject and object, antinomy of freedom and coercion, development and immutability. Dąbrowski possesses undoubtedly an unusual key to human nature. Rarely can we today hear arguments that maladjustment is better than adaptation. According to the psychiatrist, all our creativity derives exactly from our disagreement with ourselves and with the world ${ }^{4}$.

If we really want to get to know ourselves, we have to go a long way. The mythological sense of such spiritual journey is illuminated for example by Katarzyna Sikora (psychologist and Jagiellonian employee) in Mythological Met-

${ }^{3}$ Powszechna Encyklopedia Filozofii (Lublin Universal Encyclopedia of Philosophy), t. 4, Lublin 2003 [hasło: hermeneutyka (password: hermeneutics)].

${ }^{4} \mathrm{~K}$. Dąbrowski, Elementy filozofii rozwoju (Elements of the development philosophy), Warszawa 1989. 
aphors of Development $t^{5}$, based inter alia on the writings of Jung. "The boundary situations" in the Jaspers sense or, known to the Christian mystics for autopsy, the nights of life, create a unique opportunity to an internal confrontation with oneself. Sometimes a whole string of tough initiation is still too little compared with the most authentic and personal confrontation; it is as inevitable as necessary. Development occurs as a result of working out some earlier pain and the integration on a higher mental level takes place in the aftermath of overcoming a major life crisis. Other numerous antinomies also define our existence. They take place in the process of changes, which we do not have to identify as intentional. However, the important issue is how we deal with various tasks which we cannot consciously predict and whether we find ourselves, free from internal strife, in this enigmatic machine. According to our permission, the "life machine" can help us clean our souls or our minds. It will always depend on the humans themselves, whether they will become an increasingly autonomous subjects, as Immanuel Kant insisted, or will allow an anesthesia on their conscience.

The key to catch the complex issues of hermeneutics can be Jaspers' existential philosophy. According to this philosopher, the progress of our knowledge only makes our ignorance grow in basic matters and thus indicates the limits. We can give them sense only if we draw from a source other than cognizance. It is true that science shows us the remarkable and amazing things in the human being. However, the brighter it becomes, the more aware it is, that it will never be able to explore the human as a whole. We cannot make the balance and recognize that we know what is man as such, or any particular individual ${ }^{6}$.

There are many different meanings of the term interpretation. In general it can be said that anyone could add to their pool something from themselves. The concept of interpretation is close as to hermeneutics as well as analytic tradition in philosophy. Gadamer, developing his theory of approaching to understanding (interpretation), relies on the irreducible to anything hermeneutic circle, as described by Heidegger. In the circle there is hidden a positive possibility of the most original cognition. However, it will only be properly grasped when its commentary itself realizes that its first, continuous and final task is the constant

${ }^{5}$ Author's own translation. The original Polish title is: Mitologiczne metafory rozwoju (see: bibliography).

${ }^{6}$ K. Jaspers, Cztowiek (Der Mensch), trans. D. Lachowska, [in.] Filozofia egzystencji, Warszawa 1990, pp. 32-34. 
counteraction of prompting finished script by random ideas and current concepts. We are talking about the initial resource, initial overview, preliminary concepts and affirming the scientific theme by developing them on the basis of things in themselves. ${ }^{7}$

Heidegger understands "things in themselves" differently than Husserl. According to him, in order to "reach" them, we first need to grasp the sense of the whole to which meanings of these parts belong. Things in themselves are texts. The author of Being and Time draws attention to the fact that understanding, especially the understanding of one's own self, is not a human's primary tendency. Therefore, in this view, the average commonness of existence can be described as "decliningly-open," "thrown-projecting being-in-the-world." In being "close to the world" and in "the community of being" by some entity with other beings the most important issue is "the most own opportunity of being." We lack the intuitive understanding, that the ontological aspect of presence was not strongly enough overcome by "being" and therefore, according to Heidegger, we perceive the hermeneutic circle as "wrong." Only when we look at the part of existence from the perspective of the whole, can we understand that our being has been directing us to care for ourselves since we started to exist for good, before we mastered our human pronunciation. We come to understand that thanks to overcoming the differences in our understanding of the world.

If understanding is manifested first, over all our activities of the mind, it means that it is indispensable before we "eliminate" our deep-rooted subjectivity, it is indispensable as an interpretation. According to Gadamer, it is impossible for us to get rid of our prejudices, so we should be able to appreciate their presence in the cognitive process. I believe, however, that in some exceptional moments, when, for example, we lose ourselves completely in the passion of exploring the world, we may experience the heavenly moment of "the flow." At that time, hallowed like cherries, we are filled with an almost unparalleled ability of unknown origin to understand truly, or even a phenomenological insight into the essence of what we know. These rare moments of illumination do not,

${ }^{7}$ H.-G. Gadamer, Prawda i metoda (Wabrheit und Methode - Truth and Method), trans. B. Baran, Warszawa 2004, p. 368.

${ }^{8}$ M. Heidegger, Bycie i czas (Sein und Zeit-Being and Time), trans.. B. Baran, Warszawa 2004, p. 245. 
however, determine the condition of our human knowledge in general and basically they just confirm its alarming limitations.

\section{In pursuit of a sense of purpose}

Looking at the multiple interpretations of our knowledge as well as discovering the faces of them all, let us consider the concept of "paradigm" as something which, although in itself coherent, in fact functions for a very short time that means until it is overthrown by a competitive outlook. The word "paradigm" derives from the Greek word "paradeigma" (meaning pattern, model) and from the Latin "paradigma" (pattern, example). Originally the term "paradigm" was a denomination of the Platonic idea, which was a prototype of changeable things. Nowadays it is defined in linguistics as a set of declensional or conjunctional forms, appropriate for a particular type of words. In the rhetoric paradigm is extremely bright, a typical example illustrating the discussed issue. ${ }^{9}$

In his book entitled The Structure of Scientific Revolutions Thomas Kuhn defines a paradigm through the prism of his own philosophy. According to him, it is a collection of concepts and theories forming the basis of a specific science. Theories and concepts which form a paradigm are rather not subject to discussion, at least until the view of the world remains cognitively creative and usable to create detailed theories consistent with experimental (historical) data, which are dealt with by the science.

The most general paradigm is the paradigm of the scientific method as a criterion to recognize an activity as scientific. The paradigm is different from the dogma, inter alia because it is not given once and for all, but is adopted by the consensus of most scholars. In this consensus it is assumed that the paradigm can periodically be subject to fundamental changes leading to profound transformations in science associated with a scientific revolution, which undermines the sense of absolute rightness. A good paradigm should inter alia: be logically and conceptually consistent, be as simple as possible, mark only the concepts and theories which are really necessary for the science and also provide the ability to create a specific theory, consistent with the known facts.

\footnotetext{
${ }^{9}$ Powszechna Encyklopedia Filozofii (Lublin Universal Encyclopedia of Philosophy), t. 8, Lublin 2007 [hasło: "paradygmat" (password: "paradigm")].
} 
According to Th. S. Khun: "Effective research scarcely begins before a scientific community thinks it has acquired firm answers to questions like the following: What are the fundamental entities of which the universe is composed? How do these interact with each other and with the senses? What questions may legitimately be asked about such entities and what techniques employed in seeking solutions?"10

Using the collection of essays and lectures contained in the book entitled Conjectures and Refutations. The Growth of Scientific Knowledge, Karl Popper tries to prove that people can really learn from their mistakes. His theory of knowledge and development is in fact a theory of reason which assigns rational arguments with an admittedly modest but important role in the criticism of often unsuccessful attempts to solve problems. This book is also an exposition of the theory of experience, regarding observations as important tests.

Karl Popper, in his investigations, came to the conclusion that those of his friends who were admirers of Marx, Freud or Adler, were impressed by a number of points common to these theories, especially by their apparent explanatory power. "These theories appeared to be able to explain practically everything that happened within the fields to which they referred. The study of any of them seemed to have the effect of an intellectual conversion or revelation, opening your eyes to a new truth hidden from those not yet initiated. Once your eyes were thus opened you saw confirming instances everywhere: the world was full of verifications of the theory. Whatever happened always confirmed it. Thus its truth appeared manifest; and unbelievers were clearly people who did not want to see the manifest truth; who refused to see it, either because it was against their class interest, or because of their repressions which were still 'un-analysed' and crying aloud for treatment." 11

Popper's abovementioned argument shows that the persuasive power of a particular paradigm can sometimes speak more strongly than a given reality. Modern civilization can be attributed with a challenge of possibly the fullest objectifying of the agreed paradigms and adjusting the outlook on the world to the unhypocritical conditions of each individual's life. On the other hand, whether the realization of such an undertaking is within the limits of human capacities?

${ }^{10}$ Th. S. Khun, The Structure of Scientific Revolutions, [in] International Encyclopedia of Unified Science, vol. II, No. 2, United States of America 1970, pp. 4-5.

${ }^{11}$ K. R. Popper, Conjectures and Refutations. The Growth of Scientific Knowledge, London New York 1962, pp. 34-35. 
Undoubtedly many issues will be reinterpreted. Their objective verification seems to be unavailable. Besides regulating, among others, various social issues, in accordance with their sensitive essence given to them just by people is rather the task of internal judgment of legitimate individuals than some objective external laws which seem to rule the world.

Now we will trace the variety of perspectives on the problem of nonknowledge, which is undoubtedly bothering for us. The following reasoning is a specific attempt to show this issue, thanks to the hermeneutic method of overcoming differences.

\section{Mythos or logos: in the quest of an adequate language of expression}

The problem of non-knowledge - although almost intuitive - is in fact very difficult to grasp. In order to clarify it, we could successfully use the pictorial imagery of myth (mythos). The matter is harder to explain while referring to knowledge as such in the quest for theory, which in this case we do not know and for a method, which in this case we do not possess yet. In short, logos disappoints in contact with non-knowledge. You can venture to say that all our knowledge is only a small speck against the canvas of infinite non-knowledge which seems to expand every time you put another question about its impossible-to-grasp consistency. Travestying Adam Asnyk's phrase about love, we can also refer it to knowledge, saying: "Knowledge is like a shadow of a man, when you chase it, it runs away." 12

The development of civilization is progressing rapidly and it is incontestable. Despite this ascertainment, man as such is still a "problem in itself." ${ }^{13}$ Looking from a biblical perspective, we can describe ourselves as kings of creation. In the same perspective, we remain equally dependent on their Creator, as well as independent in terms of our "free" will, although perhaps we only believe that it is really independent and in our power. We examine ourselves and the world in which we live. We have already invented drugs for many diseases. Nevertheless, we remain as vulnerable to aggravating experiences as primitives. In this matter nothing has changed - we make mistakes and on their basis we con-

\footnotetext{
${ }^{12}$ A. Asnyk, http://www.cytaty.info/cytat/miloscjestjakcien.htm.

${ }^{13}$ A. J. Heschel, Who is Man, Stanford 1965.
} 
tinuously learn something new. However, usually what is new for us has already been interiorized by our ancestors in their personal experiences. Appreciating the enormous cultural and scientific development, it is still impossible not to agree with Socrates, that "we do not know anything" and therefore in the face of true wisdom we remain as vulnerable as children. Hence the comparison of our personal as well as substantial knowledge to the point that will never exceed its limits. Why does the human race last for many thousands of years and still learn; why is it still so far from the truth about itself and its appropriate origin. Going so far beyond the range of questions about our true identity is also a kind of error, is it not? $\mathrm{We}$ - as people - ought to reconsider deeply the mystery of our own humanity, should we not? You could say that the whole philosophy specifically derives from human maladjustment to the hard conditions of life and existence in the world, which still astonishes, surprises and makes the mind reflect. ${ }^{14}$ Philosophy still uses a kind of myth, plays with a chain of hypotheses which on verification escape their domain. A tiny part of philosophy becomes knowledge again. While more and more scientific theses are almost forgotten, new ones appear, which can even beat the previous theses, often only because they are new and grasp the fresh problem which has gotten away before. Science often even refutes philosophical theses. For example, in astronomy, the discovery of the heliocentric position of the sun in our planetary system was a major breakthrough, which put the previous geocentric model into question. However, no scientific discipline is self-sufficient. Perhaps this is why we still need the philosophy of science and it is still valid. Every chain of hypotheses has a beginning somewhere and its every cell is connected by a thought. Myth remains an immortal image of ideas and is like the sea from which you can always fish out some eternal truth to give it new meaning.

Myth, as a necessary complement to the mind (logos), turns out to be direct, but how mysterious a gate to understand even the most difficult puzzles whose solution it presents in the form of images; unlike logos, which uses the analysis and synthesis of the concepts of language, mathematics and dialectics. ${ }^{15}$ Interestingly, Plato's mythology gathers scholars of various disciplines of (not

${ }^{14} \mathrm{~K}$. Dąbrowski, Elementy filozofii rozwoju (Elements of the development philosophy), Warszawa 1989.

${ }^{15}$ G. Reale, Przekaz filozoficzny za pośrednictwem mitu i koncepcja wolności u Platona (Philosophical message through myth and the concept of freedom in Plato, "Człowiek w Kulturze" No. 9, Lublin 1997, p. 45. 
only) philosophy, as if beyond their borders. You can view this point as a still current incentive for interdisciplinary reflection on the shaky, for a single researcher, problem of non-knowledge. Plato used the myth to explain, for example, what "the idea of the soul" is; later Christ showed the complicated truths through simple parables. As Giovanni Reale notes for Hirsch, the mind discovers that it is unable to catch the concept of the soul, because an idea is a static entity and the soul is alive and changing. Only myth can "carry" this difficulty. ${ }^{16}$

Socrates, convinced of the value of the search for true knowledge, urged his interlocutors to get to know themselves and inclined them to look into the depths of their own souls. For this noble idea he sacrificed his own life. He paid this price for violating the rules of social order and for initiating "the wind of thought" which awakened the blissfully sleeping Greeks. ${ }^{17}$ Socrates represented the inclusive approach to ignorance, which means that he accepted the insignificance of humanity in the face of wisdom. On the other hand, you can say that he was also the opposite of a good therapist. Extremely modest in the face of wisdom, he was extremely demanding to people and tried to impose his own way of thinking on them. His purpose was to lead them to a state of doubt, without offering basically anything in return. According to him, being faced with aporia was enough to man. This negative approach to knowledge has become a direct Socratic method, the starting point for any research ${ }^{18}$. But was it right? Plato tried to answer this question, somehow balancing the output method with a positive sense of knowledge which the mind can absorb only if it was previously prepared and purified from estimations. Interestingly, this mystically illumined successor to Socrates advocated keeping one's philosophical knowledge in coverture and reserving it for a handful of insiders.

Contemporary scientists are usually Aristotelians, i.e. they manifest an $e x-$ clusive attitude towards ignorance, excluding it from their research and focus on already possessed research facilities. Aristotelians can safely live with ignorance, subordinating all their rationalities to the virtue of moderation and centering

${ }^{16}$ Ibidem, p. 43 and K. Popek, Uwiktanie bohatera w mit-drogi duchowego wyzwolenia (The entanglement of the hero into myth - ways of spiritual liberation, "Idea. Studia nad Strukturą i Rozwojem Pojęć Filozoficznych”, vol. XXVIII/1, Białystok 2016, p. 196 (http://hdl.handle.net/ 11320/5513).

${ }^{17}$ H. Arendt, Thinking Against Evil [in:] H. Arendt (posthumous book), McCarthy M. (eds.), The Life of the Mind, vol. I, New York 1978.

${ }^{18}$ Plato, Defence of Socrates, Euthyphro and Crito, trans. D. Gallop, Oxford 1997. 
between non-knowledge and knowledge. However, their research is deprived of the border situation, which Socrates and Plato indeed sought, in order to realize the enormity of ignorance and show respect for true wisdom. Aristotle, as a clear and consistent realist, found a place for non-knowledge in an area that demanded thorough exploration and which also gradually expanded the area of knowledge. In hermeneutics he expressed the view that words are signs of experiences that one received in the soul; the same experiences in every soul allow the exchange of ideas about things - also identical for everybody..$^{19}$ Practically, non-knowledge as such was not any drama for him, but just a typical research problem..$^{20}$ However, just as Aristotle pointed out: "And a man who is puzzled and wonders thinks himself ignorant (whence even the lover of myth is in a sense a lover of Wisdom, for the myth is composed of wonders)." ${ }^{21} \mathrm{~A}$ similar idea was expressed by A. J. Heschel in his book Who is Man: "Wonder, or radical amazement, is a way of going beyond what is given in thing and thought, refusing to take anything for granted, to regard anything as final. It is our honest response to the grandeur and mystery of reality our confrontation with that which transcends the given." 22

\section{A place for non-knowledge in the space of faith}

Raising the question of the status of non-knowledge and its relevance for humans we cannot forget about negative theology. Not only the Christian God, but also the God of philosophy - Absolut - definitely evades our human cognition and description. Perhaps God, as infinite, perfect and inconceivable, is beyond our ability to explore and build some knowledge about Him. As an individual and straight entity $\mathrm{He}$ is not a general concept which - according to Platonist Philo - we could easily grasp. You can also, as Gregory from Nyssa, con-

${ }^{19}$ Arystoteles, Kategorie i Hermeneutyka (Hermeneutics), trans. K. Leśniak, Warszawa 1975, p. 53.

${ }^{20}$ Compare this in A. Tarnopolski, Cztowiek wobec niewiedzy (Human in the Face of NonKnowledge, Częstochowa 2010 and Niewiedza i jej rola w świecie póżnej nowoczesności (NonKnowledge and Its Role in the World of Late Modernity), Częstochowa 2011.

${ }^{21}$ Aristotle, Metaphysics, I, 2, 982b, trans. W. D. Ross, http://classics.mit.edu/Aristotle/ metaphysics.html, [in] The Internet Classic Archive, since 1994.

${ }^{22}$ A. J. Heschel, Who is Man, Stanford 1965, chap. 4. 
sider that the nature of God, who is above the world, is so very different from the nature of His creation that even the human soul does not have access to the knowledge of his Creator. It is often believed that the cognition of God is the sole merit of His Revelation. However, man can also face up to God, considering God's Word as His most important emanation. John the Evangelist as well as St. Augustine seem to stand before God as before the "luminous darkness," stating essentially in the same way that the better they know Him, the more $\mathrm{He}$ is unknown to them. Regardless of our convictions about His existence, God is mystery to us. We can describe Him only in the negative way, using nonrational paths of cognition - applying negation, paradox, contradiction or antinomy. We say, for example, that God is not limited and that He is not fatal. Only in this way can we avoid the anthropomorphization of an entity which is completely beyond our measure. ${ }^{23}$

In the context of non-knowledge I will refer also to the philosophy of Thomas Aquinas, who talks about the potentiality of knowledge inherent in man and the possibility of transition from what is already known to what is new to us and what we can only discover by ourselves or with a teacher's guidance. According to this philosopher, a teacher-human is the cause of knowledge intermediate between God and a student's mind. ${ }^{24}$ However, not everything which is potentially knowable is also accessible for human learning. Perhaps the Angels know and understand much more than we do. Some people are willing to accept dogmas (e.g. the dogma of the Trinity). Others seek rational explanations of the most difficult paradoxes. Augustine, Anselm and Thomas, in a specific way sought to reconcile faith and reason. This combination turns out to be essential, but it also leaves a lot of understatement. Knowledge and faith will certainly complement each other, but they will not interpenetrate. ${ }^{25}$ While faith is coming up against non-knowledge, knowledge is breaking the spell of the mystery of faith. You could say that the connection is so unclear as the connection between knowledge with action, when we abstract from ethical intellectual-

${ }^{23}$ Compare this in A. Tarnopolski, Cztowiek wobec niewiedzy (Human in the Face of NonKnowledge), Częstochowa 2010.

${ }^{24}$ Thomas Aquinas, Quaestiones disputatae de veritate (qu. XI - De Magistro), [in:] Sancti Thomae de Aquino Opera omnia iussu Leonis XIII P. M. edita, vol. 22 (part 1-3), Roma 1970-1976 (and: http://dhspriory.org/thomas/QDdeVer.htm).

${ }^{25}$ John Paul II, Fides et Ratio. On the Relationship Between Faith and Reason (Encyclical Letter), Vatican 1998. 
ism. According to the Holy Bible, only the fear of God is true wisdom. ${ }^{26}$ The problem of free will is very serious. Ethical choices depend on an individual ontic structure of a human. ${ }^{27}$

\section{Humans as the measure of knowledge and non-knowledge}

Ernst Cassirer begins An Essay on Man with a reflection on man's despair in the sense of the existence of the world up to the negation of the role of introspection. It means "a crisis of human knowledge about ourselves." In this way, there is significant ambivalence between the meaning and the insufficiency of skepticism. Cassirer asks, for example, what Montaigne's sentence means for a skeptic: "The greatest thing in the world is to know how to belong to oneself." The author of An Essay on Man also makes interesting observations on human beings, located in the realm of the senses. After the Aristotelians, he appreciates selflessness and, at the same time, the leading to knowledge, questioning interest in the sense of sight. However, "the crack" which appears between Aristotle and Plato stops his original apparent naivety.

In Cassirer's "philosophical overview," which is in accordance with the "spirit of history," introversion starts to complement extraversion. It begins to mark that anthropology has a strong dependence on cosmology. Paradoxically, it means a return to the inside. An intuitive adoption of the Socratic principle of "Know thyself" takes place, as a kind of imperative (moral order) by all the major world religions: Judaism, Buddhism, Confucianism and Christianity. Heraclitus, cited by Cassirer, pointed out to the mystery of man in relation to the mystery of nature. In this way, the starting point of research on generally understood nature is changed and the development of human beings' independence of chance factors proceeds. The final transfer of attention from metaphysics and the philosophy of nature to the human being is undoubtedly made by Socrates. It was then that man was recognized as a moral agent, able to provide rational answers to reasonable questions.

Cassirer also draws attention to the medieval human's doubt in himself, because of being enlightened by God Almighty - the Creator. "The fall into sin"

${ }^{26}$ The Holy Bible (Job 28, 28), https://www.lds.org/scriptures/bible?lang=eng.

${ }^{27}$ J. Kaczmarek, Ontologiczne podstawy struktury aktów woli (Ontological Basis for the Structure of Acts of Will), [in:] Filozofia woli (Philosophy of Will), Łódź 2002, pp. 29-43. 
is an essential rupture which is impossible to exceed by humans alone on their way to reunite with God. This philosopher of culture makes a weighty assertion here. According to him, a human has no nature of his own, he is somewhere between being and non-being. Cassirer, however, appreciates religion and the fact that God is hidden for us. After all, religion - which never really indicates that hiding place - must remain a mystery, and mystery is necessary for humans.

Another basis for thinking and a premise for understanding a human as animal symbolicum is the revolutionary heliocentric theory. It turns out that - as for Pascal - a human is only a "slender reed" towards the mute universe, basically deaf to all requests. Progressive heterogenization of anthropological considerations (scientific, philosophical and theological), which with time is extremely tended to materialism, evokes a deeper and deeper cultural crisis and deepens human loss, but "in exchange" it makes him sensitive to the unexplored world of symbols. It were symbols which proved to be the key to human nature. Even before they were discovered, researchers postulated perfection of every organism, due to its being fully seated in the environment by having an adequate system of receptors and effectors. Their balance was to be "the functional circle of the animal." However, Cassirer was critical of this idea and excluded humans from this seemingly closed circle. According to Cassirer, humans in their acts certainly do not base on the stimulus-response relation, because - in their case - this mechanical process is interrupted by reflection and consideration. This problem concerns the specific "perversion" of humans in the sense of Rousseau. Cassirer also places the human being in the symbolic culture (language, myth, art and religion).

However, Cassirer's assertion is not as optimistic as it may seem. The symbolic network which humans wrap themselves up in, becomes in fact "subtler and stronger" and despite the fact that we talk almost only with ourselves, we cannot be understood. Language is not a simple code. Cassirer divides human language as follows: 1 . conceptual language - emotional language and 2. logical language - language of imagination, wherein certain languages exist in parallel (coexist). According to Cassirer, even the most formalized language expresses our desires and yearnings, rather than purely rational calculation; it is a tool for understanding, rather than ready-made knowledge. ${ }^{28}$

${ }^{28}$ E. Cassirer, An Essay on Man: an introduction to a philosophy of human culture, London 1944. 


\section{Platonism or fictionalism - the hermeneutic perspective}

There is also the problem of true knowledge in the epistemological sense. For some people mathematical fictionalism suffices to describe our knowledge, for others only mathematical Platonism presents reality, which has the status of knowledge. Frege seems to fix the problem acknowledging logical value, as a reference, only to our beliefs about fiction. Categorizing, for example, the sentence given by Frege - "Odysseus was set ashore at Ithaca while sound asleep" as true or false, you assign the name "Odysseus" with some reference. The predicate is assigned or denied actually to the reference. The logical value of a sentence will therefore depend on stating the truth or falsehood. Sentences on fiction, in our case the cited sentence on Odysseus, do not care about the truth, and as a result are neither true nor false. Sentences describing fiction cannot therefore have logical values. On the other hand, sentences in which we express our attitudes toward fiction, for example: "The Greeks believed that Odysseus was set ashore at Ithaca while sound asleep" typically have a logical value.

It is worth noting here that hermeneutics gives a different perspective of text than semantics. In Frege's philosophy meaning is public, but in hermeneutics we have to come to the sense through overcoming differences. It should however be mentioned that these two approaches are not contradictory. In order to understand the text from the perspective of hermeneutics, we find a number of difficulties impossible to cross in reality, which on the other hand - subjectively exceeded - lead us in the immeasurable depths of our own soul, acting on a kind of borderline experience. Meanwhile, according to Frege, we grasp the sense intuitively. But - let us repeat - there is no contradiction between the presented positions as Frege also allows describing things in many ways, which implies their various understanding and the ability to assign different meanings to the same words. We must remember that the meaning is always attributed in a broader context of the sentence or discourse. Although the words sound the same, we speak different languages. Of course, semantic describing may be something other than hermeneutic insight. However, in my opinion, these two perspectives are based on a common plane, which is the quite inexhaustible third kingdom of senses and thoughts, being however, part of the surrounding world, worthy of tireless discovery of new mysterious lands and seas, full of untold treasures. 
Returning to the main thread of this section, we find that Platonists usually agree with Frege, Fictionalists, however, think that sentences on fiction can also have logical value. According to Frege, language is richer than reality as the world can be described in many different ways. ${ }^{29}$ The problem was also considered by Kripke, as he referred to the argument taken from Frege's identitysentences. Ultimately, however, he fought it off. Kripke presented his conclusion on the example of "contingent scientific identification." In his example it was the identification of the mental state and physical state. Although, in his opinion, it is easier for us to understand each other just by using these type of sentences, they lead us to false convictions. Fighting them off is now the task of materialists. ${ }^{30}$ Kripke himself for example, as opposed to McGinn, did not undertake to resolve the issue of reliance between mind and body.

\section{The confrontation with non-knowledge - an analytical perspective}

Considering the status of non-knowledge, I want to try to answer the question about its mystery. I will use the example of a problem which confronts us with ignorance. Huxley, quoted by McGinn, believes that the state of our consciousness might be the result of the effect of our nerve tissue in the same sense as the appearance of Djin coming out of a lamp when it was touched by Aladdin in the well-known story. ${ }^{31}$ This perception could imply a certain uniqueness of ignorance. McGinn believes that natural idealism implies just the sort of mythological explanation of the problem which he studies, and which concerns the mind-body connection. According to this philosopher, however, there is nothing unusual here, we are just "cognitively closed" to what is a secret for us. The author derives this assertion from the theory of evolution. According to him, the concept of "cognitive closure" can be illustrated with the example that what is closed in the mind of a rat opens in the mind of a monkey. In the same way, what is closed in the mind of a monkey opens in the mind of a man. McGinn himself wonders, however, whether people's minds can be "watched" from the perspective of Humean empiricism. These are perhaps the minds of

${ }^{29}$ G. Frege, Sense and Reference, [in:] The Philosophical Review, vol. 57, issue 3, Cornell 1948, pp. 209-230.

${ }^{30}$ S. Kripke, Identity and Necessity, [in:] eds. M. K. Munitz, Identity and Individuation, New York 1971.

${ }^{31}$ C. McGinn, Can We Solve the Mind-Body Problem?, "Mind, New Series", 1989, 98(391), motto of this article. 
monkeys or dogs for which perceptual closure also means cognitive closure (the "idea" is merely a copy of "expression"), but is the human mind the same? It seems to be on the borderline of the material and spiritual worlds. McGinn (the philosopher of mind) does not enter into similar rhetoric, he does not see the need to refer to God in order to explain the problem of the specific indisposition, either. According to this philosopher of mind, awareness is the result of biological factors rather than of the supernatural power of Providence. Although, as he stated, we are currently not able to understand or explain theoretically the nature of properties of the brain responsible for conscious processes and they are at the moment noumenally closed for us, you may find them and, thanks to the advances of science, you may find an "accidental" mind-body connection, breaking the spell of the problem of the whole mystery.

In the context of this issue a lot of things puzzle us today. One is that the brain has a superior status to other organs; we also ask why it should be the brain that generates consciousness. Perhaps self-awareness could be slightly helpful in solving the problem of the "intelligible" mind-body connection. According to McGinn, pure phenomenology cannot solve this problem. From the first-person point of view, we are not even able to state whether our perception does not disappoint us. If we are wise, however, it is only in our own case. We will certainly not understand the problems of angels or ants, because they are beyond us. It should be pointed out that, according to McGinn, there are not, or at least, there should not be a philosophical mind-body problem, but only a scientific one. Nevertheless, a human, even a scientist, so much in need of a sense of coherence and consistency of their explanations, can be deceived even by the most evident illusions, for example, that the mind is something which circulates around us. People build a whole philosophy around it. ${ }^{32}$ The truth is, however, impossible to know and rarely comes forward to meet us.

We are constantly in the face of ignorance, so, willy-nilly, we have to discover, explore and get to know the unknown. For example, we are faced with the problem of the evolutionary ambiguity of human origins. This issue implies reasonable doubt in the matter of the subordination of human beings only to the laws of nature. Among many reasons this issue should also draw our attention to the uniqueness of human dignity ${ }^{33}$.

\section{Ibidem.}

${ }^{33}$ Compare this in K. Jaspers, Way to Wisdom. An Introduction to Philosophy, trans. R. Manheim, Yale 1951. 


\section{At the end}

In order to understand the significance of non-knowledge for humans, one would venture to say that the necessity of discovering both the world around and the world within us and even of finding God, becomes, however, an urge to explore and reflect on the human place in the universe and on the rule of transcendence in our lives, too. Without any doubt, we should not cease in our studies, because even if we were astray, only thanks to them do we have a chance to develop. ${ }^{34}$

A true scholar is constantly looking not only for solutions to the problems which he puts forward, but also for his own path, his method, which will be useful in reaching his purposes. Not all issues can be treated with the same yardstick. The approach to every problem should always have an element of surprise inside. Routine cannot deprive a human of their exploratory instinct, if indeed they want to be closer to the truth again. When we approach it, we already feel the climate of Arcadia. It was St. Augustine who taught such confidence in bright anticipation. However, when the area of our knowledge is expanding, paradoxically, in our consciousness it is shrinking - we are more and more convinced of the infinity of non-knowledge. Faced with the enormous wealth of this world, with the infinite universe and the omnipotence of God, we can at most be surprised and impressed by these phenomena, with which we are in communion for a moment while getting away from it all. Then we have the feeling that perhaps one day our lives, as a tiny fragments of eternity, will penetrate the mysterious veil and we will be There... To sum up this reasoning with one ascertainment, I want to say that only the hermeneutics of non-knowledge in my opinion - can demonstrate what difficult and also beautiful art is the involved search for truth about the surrounding world as well as on man as such.

${ }^{34}$ K. Popek, Wymiary btadzenia kulturowego w kontekście nieustannego poszukiwania wtasnej drogi życiowej. Inspiracje postawa Don Kichota wśród mtodzieży (Dimensions of Cultural Wandering in the Context of the Constant Search for Once's Way of Identity. Don Quixote's Attitudes as an Inspiration among Youth), "Youth Policy: Problems and Prospects", No. 5, Drohobycz - Przemyśl 2014. 


\section{Summary}

The paper is an attempt to show the specificity of human knowledge and also its insufficiency when contrasted with the feeling that we still know very little or almost nothing. The presented problem is discussed from the perspective of hermeneutics. According to the view of Socrates, only by being true to themselves can humans know their nature and actually their insignificance to the universe. Theologians explain, though, that the human condition, although very poor as such - according to the will of God - can be filled with grace. Our faith is largely founded on non-knowledge. We still face our own ignorance and the confrontation with non-knowledge becomes the cause of constantly asking new questions and of human development in general.

Key words: knowledge, non-knowledge, hermeneutics, human, mystery, quest, truth

\section{Bibliography}

Arendt H., Thinking Against Evil [in:] H. Arendt (posthumous book), McCarthy M. (eds.), The Life of the Mind, vol. I, New York 1978.

Arystoteles, Kategorie i Hermeneutyka, tłum. K. Leśniak, Warszawa 1975.

Aristotle, Metaphysics, trans. W. D. Ross, http://classics.mit.edu/Aristotle/metaphysics.html, [in] The Internet Classic Archive, since 1994.

Asnyk A., http://www.cytaty.info/cytat/miloscjestjakcien.htm.

Cassirer E., An Essay on Man: an introduction to a philosophy of human culture, London 1944.

Dąbrowski K., Elementy filozofii rozwoju (Elements of the development philosophy), Warszawa 1989.

Descartes R., Discourse on the Method, The Radical Academy 2006, http;//www.earlymodernt exts.com/pdf/desdisc.pdf.

Frege G., Sense and Reference, [in:] The Philosophical Review, vol. 57, issue 3, Cornell 1948, pp. 209-230.

Gadamer H.-G., Prawda i metoda (Wabrheit und Methode - Truth and Method), thum. B. Baran, Warszawa 2004.

Heidegger M., Bycie i czas (Sein und Zeit-Being and Time), przeł. B. Baran, Warszawa 2004.

Heschel A. J., Who is Man, Stanford 1965.

Jaspers K., Cztowiek, tłum. D. Lachowska, [in.] Filozofia egzystencji, Warszawa 1990. Original version: Der Mensch, [in:] Der philosophische Glaube, München 1948.

Jaspers K., Way to Wisdom. An Introduction to Philosophy, trans. R. Manheim, Yale 1951.

John Paul II, Fides et Ratio. On the Relationship Between Faith and Reason (Encyclical Letter), Vatican 1998.

Kaczmarek J., Ontologiczne podstawy struktury aktów woli (Ontological Basis for the Structure of Acts of Will), "Zeszyty Naukowe WSHE”, No. 6: Filozofia woli (Philosophy of Will), Łódź 2002, pp. 29-43.

Khun Th. S., The Structure of Scientific Revolutions, [in] International Encyclopedia of Unified Science, vol. II, No. 2, United States of America 1970.

Kripke S., Identity and Necessity, [in:] eds. M. K. Munitz, Identity and Individuation, New York 1971, pp. 135- 164. 
McGinn C., Can We Solve the Mind-Body Problem?, "Mind, New Series", 1989, 98(391), pp. 349366.

Plato, Defence of Socrates, Euthyphro and Crito, trans. D. Gallop, Oxford 1997.

Popek K., Uwiktanie bohatera w mit - drogi duchowego wyzwolenia (The entanglement of the hero into myth - ways of spiritual liberation), "Idea. Studia nad Strukturą i Rozwojem Pojęć Filozoficznych”, No. XXVIII/1, Białystok 2016, pp. 191-216.

Popek K., Wymiary btadzenia kulturowego w kontekście nieustannego poszukiwania wtasnej drogi $\dot{z} y$ ciowej. Inspiracje postawa Don Kichota wśród mtodzieży (Dimensions of Cultural Wandering in the Context of the Constant Search for Once's Way of Identity. Don Quixote's Attitudes as an Inspiration among Youth), „Youth Policy: Problems and Prospects”, No. 5, Drohobycz - Przemyśl 2014, pp. 242-247.

Popper K. R., Conjectures and Refutations. The Growth of Scientific Knowledge, London - New York 1962.

Powszechna Encyklopedia Filozofii (Lublin Universal Encyclopedia of Philosophy), t. 4, Lublin 2003 [hasło: hermeneutyka (password: hermeneutics)].

Powszechna Encyklopedia Filozofii (Lublin Universal Encyclopedia of Philosophy), t. 8, Lublin 2007 [hasło: paradygmat (password: paradigm)].

Reale G., Przekaz filozoficzny za pośrednictwem mitu i koncepcja wolności u Platona (Philosophical message through myth and the concept of freedom in Plato, "Człowiek w Kulturze" No. 9: Wolnosic we wspótczesnej kulturze (Freedom in contemporary culture), Lublin 1997, pp. 41-50.

Scheler M., The Idea of Man, trans. C. Nabe, "Journal of the British Society for Phenomenology" No. 9, Oct 1978, pp. 184-198.

Sikora K., Mitologiczne metafory rozwoju, [in:] Hermeneutyka a psychologia, eds. A. Gałdowa, Kraków 1997.

Tarnopolski A., Cztowiek wobec niewiedzy (Human in the Face of Non-Knowledge), Częstochowa 2010.

Tarnopolski A., Niewiedza i jej rola w świecie późnej nowoczesności (Non-Knowledge and Its Role in the World of Late Modernity), Częstochowa 2011.

The Holy Bible, https://www.lds.org/scriptures/bible?lang=eng.

Thomas Aquinas, Quaestiones disputatae de veritate (qu. XI - De Magistro), [in:] Sancti Thomae de Aquino Opera omnia iussu Leonis XIII P. M. edita, vol. 22 (part 1-3), Roma 1970-1976 (and: http://dhspriory.org/thomas/QDdeVer.htm).

Katarzyna Popek - doktor nauk humanistycznych w zakresie filozofii, Uniwersytet Łódzki 